\title{
Effects of Hydraulic Overload on Biological Nutrient Removal Efficiencies in Wastewater Treatment Systems
}

\author{
Thandeka Y.S. Jwara, Paul Musonge and Babatunde F. Bakare
}

\begin{abstract}
The control of eutrophication in receiving water bodies and adherence to the current wastewater treatment environmental laws, has led to extensive use of the biological nutrient removal process (BNR) in wastewater treatment practice. Wastewater treatment is a sensitive and complex phenomenon which requires careful design and operation. Results of a comprehensive study on BNR efficiencies in relation to the hydraulic load was conducted for Darvill Wastewater Treatment Plant (WWTP). The plant influent and effluent nutrients (ammonia and soluble reactive phosphorus (SRP) concentrations were determined using standard laboratory testing methods. Calculations of the BNR efficiencies were used to determine the effects of high hydraulic loads to the biological treatability of the activated sludge for the period September 2016-November 2017. At hydraulic loads above design capacity the BNR efficiency was found to be at an average of $40 \%$ and SRP removal efficiency being $64 \%$ for the period of the study. The BNR efficiency had an inversely proportional relationship to the hydraulic load into the plant with ammonia removal being mostly affected. When the plant is hydraulically overloaded the BNR process is adversely affected.
\end{abstract}

Keywords - Biological nutrient removal, hydraulically overloaded plants, nutrient removal efficiency, wastewater treatment

\section{INTRODUCTION}

Wastewater treatment has over the last decade become an essential step to improved recipient water quality, reduced water pathogenicity and improved human health. To control eutrophication in receiving water resources, biological nutrient removal (BNR) of nitrogen and phosphorus has been extensively used in wastewater treatment systems, both for the upgrade of existing wastewater treatment plants (WWTPs) and the design of such new facilities [1].These WWTPs are further subject to comply with the national legislative requirements of the Department of Water and Sanitation (DWS) in order to preserve and protect the water resources that WWTPs discharge

Manuscript received October 19, 2020. This work was supported in part by the Institute of System Science, Durban University of Technology, Durban, South Africa

Thandeka Y.S. Jwara, is with the Institute of System Science, Durban University of Technology, Durban, South Africa.

Paul Musonge is with the Institute of System Science, Durban University of Technology, Durban, South Africa.

Babatunde F. Bakare is with the Department of Chemical Engineering, Mangosuthu University of Technology, Durban, South Africa. into. In the case of BNR, the activated sludge reactor is the most commonly used technology [2]. Traditionally, the complexity associated with implementing BNR in wastewater treatment systems has been largely in terms of balancing the competing requirements for nitrogen $(\mathrm{N})$ and phosphorus $(\mathrm{P})$ removal, particularly with respect to the influent readily biodegradable chemical oxygen demand (rbCOD) which becomes a substrate for the microorganisms [3].

Enhanced biological phosphorous removal (EBPR) employs the extended polyphosphate storage capacity of individual microorganisms known as the polyphosphate-accumulating organisms (PAOs). These PAOs require anaerobic conditions in order to assimilate organic matter such as volatile fatty acids (VFAs) with the release of phosphorus from stored polyphosphate [4]. Phosphate is taken up, under aerobic conditions, by the PAOs [5] and as has been demonstrated, under anoxic conditions in the presence of nitrate by denitrifying-polyphosphate-accumulating organisms (DPAOs) [3][6]. The DPAOs, in fact, denitrify nitrite and nitrate $\left(\mathrm{NO}^{\mathrm{x}}\right)$ using the organic matter previously stored under anaerobic conditions [6]. Therefore, DPAOs optimize denitrification, which can be limited by the low quantity of organic matter available in the anoxic reactor. Moreover, phosphate uptake occurs either under anoxic or aerobic conditions increasing phosphorus removal efficiencies [7].

In the case of $\mathrm{N}$ removal, typically, the nitrogen $(\mathrm{N})$ found in the wastewater treatment system is present in the of $\mathrm{NH}_{3}$, ammonium ions $\left(\mathrm{NH}^{4+}\right)$, nitrites $\left(\mathrm{NO}^{2-}\right)$ and nitrates $\left(\mathrm{NO}^{3-}\right)$. Ammonia and Ammonium ions are frequently referred to as "ammonia nitrogen". Ammonia and ammonium ions are the most reduced forms of $\mathrm{N}$ and are often products of organic decomposition. Nitrite is, however, the intermediary, with nitrate being the end product of organic oxidation during nitrification [2]. The removal of ammonia nitrogen in wastewater through nitrification is mediated by specific chemical autotrophic nitrifying bacteria. [6] suggests that these bacteria obtain their carbon requirement (anabolism) from dissolved carbon dioxide $\left(\mathrm{CO}_{2}\right)$ and their energy requirement (catabolism) for biomass synthesis from oxidizing the ammonia nitrogen to nitrite and nitrate. In the activated sludge reactor, the autotrophic nitrifying bacteria have considerably lower growth 
coefficients $\left(1 / 5^{\text {th }}\right)$ as compared to the heterotrophic bacteria which are responsible for chemical oxygen demand (COD) removal.

Industrial effluent is observed to have high concentration of $\mathrm{N}$ and a low $\mathrm{C} / \mathrm{N}$ ratio. The main difficulties in maintaining high nitrification efficiency when treating low $\mathrm{C} / \mathrm{N}$ wastewaters are changes in influent concentration and flow, which may also affect the dissolved oxygen level in the reactor, and $\mathrm{pH}$ due to fluctuating industrial operations [8].

The operating WWTP used for this study is Darvill WWTP. The WWTP is situated in Pietermaritzburg and owned by Umgeni Water. The plant is operated on the basic design of the conventional activated sludge configuration which consists of primary settling tanks (PST), activated sludge reactor, secondary settling tanks (SST) and chlorine disinfection of final effluent. The WWTP discharges into the Umsunduzi River. The discharge limits for $\mathrm{NH}_{3}$ and SRP are $6 \mathrm{mg} \mathrm{N} / 1$ and $1 \mathrm{mg} \mathrm{P} / 1$ respectively. It has an average dry weather flow (ADWF) design capacity of $65 \mathrm{Ml} / \mathrm{d}$; however, the WWW has been receiving wastewater influent flow as high as $120 \mathrm{Ml} / \mathrm{d}$ for the period of September 2016-November 2017. Darvill WWTP had a challenge with nutrient removal through this period thus compromising the WWTP legal compliance. The study seeks to analyze the effects of the high influent flows (hydraulic overload) on the BNR process. This analysis study is particularly observing impacts on the nutrients, ammonia and SRP.

\section{METHOD}

Darvill wastewater works was used as a case study to conduct this study. The main focus area is the performance of the activated sludge reactor when subjected to flows above its design capacity of $65 \mathrm{Ml} / \mathrm{d}$.

\section{Sampling}

A one litre representative grab sample of primary effluent and final effluent was collected and appropriately labelled every morning at 8:00 am. Primary effluent is the supernatant from the primary settling tank that goes into the activated sludge reactor before BNR. The collection times and sampling points were kept constant throughout the period of the study. Once the samples were collected they were stored in a cooler box with ice and transported immediately to the laboratory for analysis and were handled within three days after drop-off.

\section{Laboratory Analysis}

The ammonia and SRP concentrations were determined as outlined by the Standard Methods (1995) for ammonia and SRP determination. The samples were centrifuged at $5000 \mathrm{rpm}$ for 5 minutes (Megafuge 3.0 R) and the clear supernatants were analyzed accordingly. The DR900 Spectrophotometer instrument was used to determine the concentration of $\mathrm{NH}_{3}$ and SRP.

\section{Statistical Analysis and calculations}

The concentrations from the lab analyses were used to calculate the BNR efficiency of each parameter in the primary effluent and final effluent sample. The plant inflow was recorded hourly and an average for the day was recorded.

$$
E f f=\frac{P E C-F E c}{P E C}
$$

Where:

Eff - Removal efficiency

PEc - Primary effluent concentration

FEc - Final effluent concentration

Microsoft Excel, was used for the scatter plots to compare the BNR efficiencies to the plant inflow.

\section{RESULTS}

The plant flows for 2016-2017 were plotted and compared to the removal efficiencies of ammonia and SRP. This was done to establish the effects of hydraulic overloading on the BNR process of Darvill WWTP.

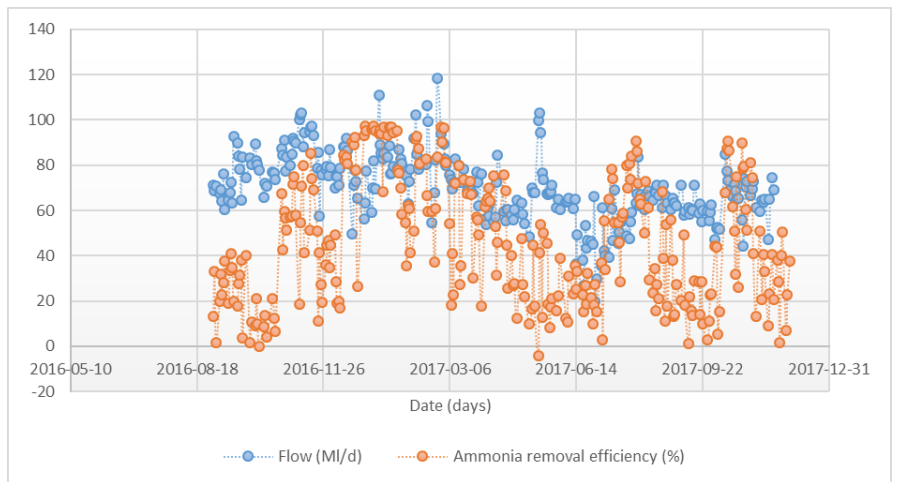

Fig. 1 Ammonia removal efficiency

The graph (see Fig. 1) suggests that the $\mathrm{NH}_{3}$ removal efficiency is mainly inversely proportional to the plant influent flows. The removal efficiency average of ammonia during the period of September 2016 and November 2017 was found to be $42 \%$ and $38 \%$ respectively.

The design capacity of Darvill WWTP is $65 \mathrm{Ml} / \mathrm{d}$, however, the data shows numerous periods where the plant was operating above the design capacity, experiencing peaks as high as 120 $\mathrm{Ml} / \mathrm{d}$. The lowest ammonia removal efficiency was seen in June $2017(23.2 \%)$ with a flow of $48.9 \mathrm{Ml} / \mathrm{d}$ and November 2016 on 
average had the highest influent flows $(88 \mathrm{Ml} / \mathrm{d})$. This was largely associated with procurement delays of faulty subsurface aerators which resulted in process upsets. This was also suspected to be as a result of the cold weather temperatures experienced by the WWTP during winter which could reach a minimum of $5{ }^{\circ} \mathrm{C}$. The denitrification rate is significantly affected by lower temperatures in wastewater treatment systems and the denitrification rate decreases 10 times linearly as compared to temperatures of $20{ }^{\circ} \mathrm{C}$ and above [9] [10] [11]. These temperature effects on BNR are predominantly related to the low growth rate of the nitrifying bacteria at low temperatures [12]. A study [13] found that Nitrogen removal at low temperatures could be achieved by operating the WWTP at higher mixed liquor suspended solids (MLSS) concentration of the range 6000- $8000 \mathrm{mg} / \mathrm{l}$ and an adequate supply of COD for denitrification. This however could not be practiced at Darvill WWTP as the design MLSS concentration was $4500 \mathrm{mg} / \mathrm{l}$ and higher MLSS concentrations led to other process challenges i.e. sludge bulking. Wastewater treatability depends largely on the characteristics of the sludge and the activated sludge reactor conditions [6]. Higher influent flows come with higher organic and nutrient loads hence compromising the BNR process. It was seen that for the most part of the months of the study the ammonia removal efficiency was below $75 \%$ (see

Table 1) this shows that the Darvill WWW treatment process was negatively affected by the hydraulic overload.

TABLE I AVERAGE MONTHLY INFLUENT FLOW AND AMMONIA REMOVAL EFFICIENCY DATA

\begin{tabular}{|l|c|c|}
\hline $\begin{array}{l}\text { Month/Yea } \\
\text { r }\end{array}$ & Influent Flow average & $\begin{array}{l}\text { Removal efficiency } \\
\text { average }\end{array}$ \\
\hline Sep-16 & 73,7 & 24,1 \\
\hline Oct-16 & 79,3 & 27,6 \\
\hline Nov-16 & 88 & 51,9 \\
\hline Dec-16 & 75 & 63 \\
\hline Jan-17 & 81,1 & 87 \\
\hline Feb-17 & 84,5 & 68,9 \\
\hline Mar-17 & 74,7 & 55,1 \\
\hline Apr-17 & 60,9 & 50,2 \\
\hline May-17 & 70,8 & 25,7 \\
\hline Jun-17 & 48,9 & 23,2 \\
\hline Jul-17 & 52,2 & 59,2 \\
\hline Aug-17 & 66,4 & 42,3 \\
\hline Sep-17 & 60,8 & 19,8 \\
\hline Oct-17 & 64,9 & 60 \\
\hline Nov-17 & 64,2 & 29 \\
\hline
\end{tabular}

The average SRP removal efficiency during the period of 2016 and 2017 was observed to be $61.6 \%$ and $65.9 \%$ for the two years respectively. There is an inversely proportional relationship (see Fig. 2). The results suggest that at higher influent flows more detrimental effect are observed on the ammonia removal efficiency than that SRP. This is mainly due to the fact that ammonia is removed during the nitrification process in the activated sludge reactor. The amount of dissolved oxygen available in the activated sludge reactor becomes insufficient and the growth of the autotrophic nitrifying bacteria becomes compromised at flows above design capacity. There is also a significant increase in organic loading which also requires and competes for the available dissolved oxygen in the activated sludge reactor. The POAs are able to compete successfully with the other microorganisms for substrate in completely aerobic activated sludge systems [14]. The decline of the SRP removal efficiency is largely due to the wash out of POA's with the final effluent in instances of hydraulic overload. [15] suggested that WWTPs experience reduced SRP removal rates at low temperatures due to reduced biological reaction rates. However, Darvill WWTP SRP removal efficiency was not significantly adversely affected by the low temperatures. Any process upsets can also affect the performance of the microorganisms in the activated sludge reactor. Therefore, monitoring and regulation of online parameters such as $\mathrm{pH}, \mathrm{DO}$, SRP and nutrient pollutants (phosphorus and $\mathrm{NH}^{4+}-\mathrm{N}^{-} / \mathrm{NO}^{2-}-\mathrm{N} / \mathrm{NO}^{3-}-\mathrm{N}$ ) can be helpful in achieving and maintaining high nutrient removal in wastewater treatment systems [16].

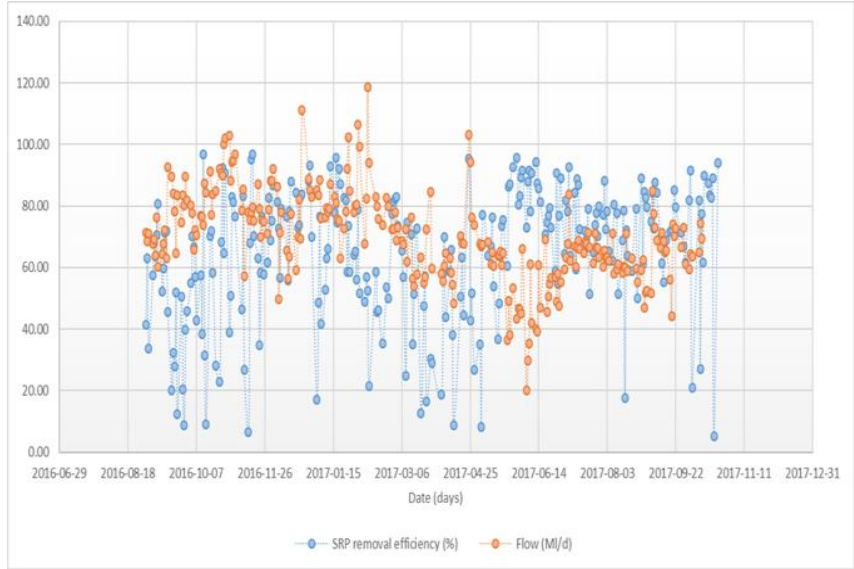

Fig. 2 SRP removal efficiency 
TABLE II AVERAGE MONTHLY INFLOW AND SRP REMOVAL EFFICIENCIES DATA

\begin{tabular}{|l|l|l|}
\hline Month/Year & $\begin{array}{l}\text { Influent flow average } \\
\text { (Ml/d) }\end{array}$ & $\begin{array}{l}\text { Removal efficiency average } \\
(\%)\end{array}$ \\
\hline Sep-16 & 74,7 & 47,4 \\
\hline Oct-16 & 84,0 & 56,6 \\
\hline Nov-16 & 80,3 & 64,4 \\
\hline Dec-16 & 76,5 & 77,8 \\
\hline Jan-17 & 80,9 & 69,0 \\
\hline Feb-17 & 84,6 & 54,3 \\
\hline Mar-17 & 66,3 & 52,0 \\
\hline Apr-17 & 67,8 & 49,1 \\
\hline May-17 & 57,3 & 66,6 \\
\hline Jun-17 & 49,0 & 80,8 \\
\hline Jul-17 & 66,3 & 74,0 \\
\hline Aug-17 & 60,5 & 69,1 \\
\hline Sep-17 & 66,5 & 73,0 \\
\hline Oct-17 & 69,3 & 70,6 \\
\hline
\end{tabular}

The average monthly influent flow and SRP removal efficiencies data (see Table 2) shows that the highest SRP removal (80.8\%) was observed in June 2017 at a low influent flow of $49 \mathrm{Ml} / \mathrm{d}$. This shows that the process upset during this time had little to no effect on the POA's ability to uptake the phosphorus in the activated sludge reactor. This is mainly due to the fact that POAs are facultative microorganisms which means they can survive in presence and absence of oxygen.

\section{ACKNOWLEDGMENT}

Sincere acknowledgments go to the following people for their support on the successful completion of this project:

- Prof P. Musonge and Prof B. Bakare, my Supervisors - For encouragement and invaluable input in this study

- Jwara family for the patience and support.

- Lubanzi and Bandile Mthembu for their unfailing love.

\section{REFERENCES}

[1] M. Speârandio and P. Etienne. (March 2000). Estimation of wastewater biodegradable COD fractions by combining respirometric experiments in various So/Xo ratios. Wat. Res. [Online]. 34(4), pp. 1233-1246. Available: https://doi.org/10.1016/S0043-1354(99)00241-9

[2] M. Adonadaga. (August 2014). Nutrient Removal Efficiency of Activated Sludge Plants Treating Industrial and Municipal Wastewater in Ghana. Journal of Environment Pollution and Human Health. [Online]. 2(3) pp. 58-62. Available: http://pubs.sciepub.com/jephh/2/3/1/

[3] Z. Hu., D. Houweling, and Dold, P., (March 2012). Biological Nutrient Removal in Municipal Wastewater Treatment: New Directions in Sustainability. Journal of Environmental Engineering. [Online]. 138(3) pp. 307-317. Available: https://www.researchgate.net/publication/273024416_Biological_Nutrie nt_Removal_in_Municipal_Wastewater_Treatment_New_Directions_in Sustainability

[4] P. J. Pybus, et. al, Handbook of the Operation of Wastewater Treatment Works. Water Institute of South Africa, Water Research Council and East Rand Water Care Company, (2002).
[5] M.K. De Kreuk, "Aerobic Granular Sludge Scaling up a new technology," $\mathrm{Ph}$.D. dissertation.Dept. Agriculture, Technical University of Delft, Delft. Netherlands, 2006.

[6] M. Henze, M.M.C. Van Loosdrecht, G.A. Ekama and D. Brdjanovic. Biological Wastewater Treatment, Principles, Modelling and Design. London.: IWA Publishing, 2008, pp. 1-511

[7] H. Monclús, J. Sipma, G. Ferrero, J. Comas, I. Rodriguez-Roda (October 2009). Optimization of biological nutrient removal in a pilot plant UCT-MBR treating municipal wastewater during start-up. Desalination. [Online]. 250(2). pp. 592-597. Available: https://doi.org/10.1016/j.desal.2009.09.030

[8] J.L Campos, J.M. Garrido, A. Mosquera-Corral, and R. M'endez. (July 2007). Stability of a nitrifying activated sludge reactor. Biochemical Engineering Journa.l [Online]. 35(1). pp. 87-92. Available: https://doi.org/10.1016/j.bej.2007.01.002

[9] J. Guo, L. Zhang, W. Chen, F. Ma, H. Liu, and Y. Tian (April 2013). The regulation and control strategies of a sequencing batch reactor for simultaneous nitrification and denitrification at different temperatures. Bioresour. Technol. [Online]. 133. pp.59-67. Available: https://doi.org/10.1016/j.biortech.2013.01.026

[10] E. Choi, D. Rhu, Z. Yun,.and, E. Lee. (May 1998). Temperature effects on biological nutrient removal system with weak municipal wastewater. Wat. Sci. Technol. [Online]. 37 (9). pp. 219-226. Available: https://doi.org/10.1016/S0273-1223(98)00291-1

[11] S.M. Hocaoglu, G. Insel, E.U Cokgor, and D. Orhon, (June 2011). Effect of sludge age on simultaneous nitrification and denitrification in membrane bioreactor. Bioresour. Technol. [Online]. 102(12). pp. 6665-6672. Available: https://doi.org/10.1016/j.biortech.2011.03.096

[12] W. Ying Xin Wu. (2015). Development of a Plant-Wide Steady-State Wastewater Treatment Plant De sign and Analysis Program. Masters Thesis. University of Cape Town http://hdl.handle.net/11427/13724

[13] L. Ydstebø, T. Bilstad, and J. Barnard. (Jul. - Aug., 2000). Experience with Biological Nutrient Removal at Low Temperatures. Water Environment Research. [Online]. (72(4) pp. 444-454. Available: https://www.jstor.org/stable/25045401

[14] M.C. Wentzel, L.H., Lötter, R. E. Loewenthal, and G.v.R. Marais. (October 1986). Metabolic behaviour of Acinetobacter spp. in enhanced biological phosphorus removal - a biochemical model. Water SA. [Online]. 12(4). pp. 209-224. Available:

[15] Y.V. K. Reddy, S. Adamala, E. K, Levlin, and K. S. Reddy. (December 2017). Enhancing nitrogen removal efficiency of domestic wastewater through increased total efficiency in sewage treatment (ITEST) pilot plant in cold climatic regions of Baltic Sea. International Journal of Sustainable Built Environment. [Online]. 6, 351-358. Available: https://doi.org/10.1016/j.ijsbe.2017.05.002

[16] Y. Wang, Y. Peng, and T. Stephenson. (July 2009). Effect of influent nutrient ratios and hydraulic retention time (HRT) on simultaneous phosphorus and nitrogen removal in a two-sludge sequencing batch reactor process. Bioresource Technology. [Online. 100(14). pp. 3507-3512. Available: https://doi.org/10.1016/j.biortech.2009.02.026 